\title{
ASSESSMENT OF COMPETITIVE CONFRONTATION BETWEEN CHINA AND THE USA IN THE GLOBAL MARKET
}

Olga Mirolyubova, International Graduate School of Management, Engineering-Economic Institute, Saint-Petersburg State Polytechnical University, Russia

Elena Schislyaeva", International Graduate School of Management, Engineering-Economic Institute, Saint-Petersburg State Polytechnical University, Russia

Abstract: Competition between US and China on global oil market has specific differences and long lasting history. Contradictions of China and the United States developed in the situation with the Crimea. The article reflects the confrontation in the political and economic sphere, as well as the trends in the development of relations between countries. Authors have applied the methods of analysis, historical method and synthesis in the research.

Keywords: globalization, economic growth, policy of investment, international crisis, resources, political situation.

JEL classification: 016,040

\section{PROCENA KONKURENTSKE KONFRONTACIJE IZMEĐU KINE I SAD NA GLOBALNOM TRŽIŠTU}

Sažetak: Konkurencija između SAD i Kine na globalnom tržištu nafte ima specifične različitosti $i$ dugotrajnu istoriju. Kontradiktornosti koje nalazimo kod Kine i SAD razvile su se u situaciji sa Krimom. Ovaj rad oslikava konfrontaciju u političkoj $i$ ekonomskoj sferi, kao i kretanja u razvoju odnosa izmedu zemalja. Autori su u istraživanju primenili metode analize, istorijski metod i sintezu.

Ključne reči: globalizacija, ekonomski rast, politika investicija, međunarodna kriza, resursi, politička situacija.

\footnotetext{
*elena@igms.info
} 


\section{INTRODUCTION}

Trends in globalization of the international economy are noticeable in all aspects of business activities. Enlargement of international industrial enterprises and interpenetration of capital and power increase the dependence of all national economies, as well as politics of individual nations towards entire regions. Traditional concepts of developed and developing countries are changing as the single global market is evolving. The silent opposition between the USA and China seems to be very important to look into.

Recently China has become one of the motivators of Washington foreign policy. Indices of Chinese economic development, aggressive investment policy in the Middle East, in the zones of the U.S. investment activity prove that this opposition is growing. According to analysts, the Chinese economy is likely to outperform U.S. economy and take the lead. Hence, it is obvious that the USA is trying to stop Chinese economic growth by means of blocking access to energy and high-tech resources. In spite of the crisis, China retains steadily high growth rates. Average growth rates of the American economy are 2 percent per year, but in China they are 10 percent per year. At the moment America excels China at GDP, however, the government debt, which is almost equal to the American GDP, does not let American economy gather pace. China does not have such problems and it is important to note that the Chinese are major creditors of America. Of course, China retains high growth rates of GDP due to exports and expansion of the domestic market, which comprises around 1.3 billion people. Three years ago the share of export was $60 \%$, but with the arrival of the crisis, China reduced exports, including those to the USA and the EU countries and, as a result, the share of foreign trade in the total GDP declined to $40 \%$. China systematically develops its own production, taking the opportunities of its economy, investing in high technology, demonstrating its desire to become an economy based on high technology.

\section{CHINA'S AUTOMOTIVE INDUSTRY AND POSSIBLE PROBLEMS}

China's wish to improve is proved by investments in the industries where Chinese economy falls behind. Purchase of Swedish Volvo and British MG Cars, investments in Saab brightly demonstrate its aspiration to use knowledge and technologies of the Western automotive industry, which China carefully studies and develops in its territory together with other technologies and uses this experience as the basis to grow its national industries with the use of considerably cheaper labor. China has been ranked first in car-making sector for two years running, having outperformed the USA and Japan. Export of cars has 
87 | ASSESSMENT OF COMPETITIVE CONFRONTATION BETWEEN CHINA AND THE USA IN THE GLOBAL MARKET

declined in the period of the crisis, but instead there is increase in the domestic demand.

The Chinese buy more than 10 million cars annually. It provokes appearance of new problems with parking, junctions and improvement of road quality, but in China such problems are being successfully solved and, thus, they are stimulating development of such industries as road-building, oil processing, etc.

However, economic growth and further development of the domestic manufacturing sector entail increasing demand for energy resources, in which China is willing to invest even more significant funds. But, as energy products become more expensive, the inflation rate also increases in China. In 2010 the inflation rate in the country was $3.3 \%$. This year, according to the official statistics, it will be 4 or $5 \%$, and, according to the business people, the real inflation rate will be $6-7 \%$ higher. Of course, this entails significant social problems. Loss of control over investments in the regions which are strategically important for China stops the growth rates planned by Beijing.

\section{THE POSITION OF THE U.S. ADMINISTRATION TOWARDS CHINA'S INVESTMENTS}

It is interesting to analyze the position of the U.S. administration towards the countries actively accepting investments from China. Washington's position in relation to Libya can serve as the most striking and recent example. Over the past five years China has made large-scale energy investments in the east of Libya, and today, as a result of military operations in this country, Chinese companies have lost hundreds of millions of dollars. Beijing perfectly understands that the military intervention is mostly the game against China, which needs energy resources. These general considerations are confirmed by the following facts. China has been operating in Africa for over twenty years and during this period it has become one of the key partners of Libya, Niger, Angola and other countries. At the same time China invests a lot of money not only in production of oil, uranium and other strategically important resources, but also in the manufacture. It is interesting to analyze the data concerning oil export to China from these countries (see Table 1). 
Table 1

Data analysis of oil export to China from different countries

\begin{tabular}{crcr}
\hline Country & $\begin{array}{c}\text { Tons of oil } \\
\text { (Jan. 2010) }\end{array}$ & Country & $\begin{array}{r}\text { Tons of oil } \\
\text { (Jan. 2010) }\end{array}$ \\
\hline Angola & 3360687 & Indonesia & 265365 \\
Saudi Arabia & 2908350 & Congo & 388409 \\
Russian Federation & 1273039 & Malaysia & 198796 \\
Sudan & 1149869 & Brunei & 138580 \\
Iran & 1085742 & Equatorial Guinea & 137526 \\
Kuwait & 749234 & Qatar & 137012 \\
Oman & 685001 & Gabon & 129199 \\
Brazil & 681931 & Australia & 75262 \\
Kazakhstan & 681780 & Cuba & 58170 \\
Iraq & 655897 & Vietnam & 57617 \\
Libya & 622209 & Ecuador & 41125 \\
OAE & 541746 & Thailand & 34140 \\
Yemen & 389386 & Mongolia & 18723 \\
Venezuela & 363371 & USA & 1 \\
\hline Total:
\end{tabular}

Note. Adapted from: The business paper Vestnik Kitaya, www.chinapro.ru/rubrics/2/4471/?p=0

The increased attention of the USA to the oil-bearing regions of this continent is not accidental: according to the forecasts of oil analysts, by 2015 the share of American oil imports from Africa will have reached 25\%. In order to control the situation in 2008 the Unified Command of the United States Armed Forces was set up in Africa (Africom). The main idea promoted by this organization is to maintain order, suppress tribal clashes which destabilize the situation in the regions where American companies operate and lead preventive fight against terrorism. Libya`s rejection to cooperate with Africom resulted in Gaddafi`s death.

Revolutions in the African countries, cooperating with China too actively, and other steps, aimed at expulsion of the Chinese companies, demonstrate the mentioned opposition.

Let us now analyze the situation concerning Niger. A few years ago the government of Niger began selling uranium to China and concluded an agreement with a Chinese oil company to develop oil fields discovered in the north of the country. In February, 2010 Niger saw a revolution and as a result Beijing lost some contracts. China began oil field development in Sudan, where tribal clashes immediately escalated and followed by a referendum concerning dissolution of the country. When oil was discovered in the Ivory Coast, China also invested in its extraction, but in November, 2010 the country began a ŠKOLA BIZNISA, 2/2014, 85 - 90 
89 | ASSESSMENT OF COMPETITIVE CONFRONTATION BETWEEN CHINA AND THE USA IN THE GLOBAL MARKET

colour revolution. This spring, after intervention of the UN and a series of rocket attacks on the residence of the former president Gbagbo, President Outtara, supported by the West, came to power.

\section{THE U.S. STRATEGY IN ASIA CONCERNING THE OIL LINE}

The U.S. tactics in Asia is a bit different. The main aim of the American policy is to close transport and energy routes. First of all, it concerns the oil line IranPakistan-India-China and transport routes linking China with the ports of the Indian Ocean, through which China receives Middle East oil. A lot of these routes go through Pakistan, which actively cooperates with Beijing and participates in projects concerning a deep-water port construction in the territory of Pakistan, which serves for receiving oil tankers and as a naval base. Washington's response was the strategy of "AfPak", which involved transposition of the fight against terrorism to the territory of Pakistan. The consequences of this strategy are instability in the region and numerous deaths of civilians because of American air strikes. At the same time, bin Laden was eliminated, although there is still no evidence of it, and the Pakistani military has become a target of terrorists, revenging for bin Laden`s death. Politicians and the world media keep claiming that such an unstable country cannot possess nuclear weapons, because it can fall into the hands of terrorists. All this forms a request for external intervention, and China perfectly understands who this campaign is aimed against. Beijing explicitly claims that Pakistan is its strategic partner and indicates that any steps taken against Pakistan will be considered as a challenge to China.

The same game is played around the projects of China in Sri Lanka, Bangladesh, Myanmar and other countries of the region. In the summer of 2010 the construction of oil and gas pipelines linking China with the ports of Myanmar began. International organizations refer to all partners, including China itself, as the worst human right abusers whose domestic policy needs to be intervened from outside.

\section{THE U.S. POLICY IN THE MIDDLE EAST - MAINTAINING CONFRONTATION}

The main U.S. policy tool is to maintain the confrontation between China and India, subject to its influence China's southern neighbors and control the Straits of Malacca - a narrow passage between the Malay Peninsula and the Indonesian island of Sumatra, where all the Near East oil tankers go along to the Pacific ports of China.

Repartition of the Middle East continues. On $15^{\text {th }}$ November, 2011 oil embargo against Syria came into operation on the back of the unstable situation. It 
forbids the European companies to buy oil and oil products from that country. Syria exports about 100 thousand barrels per day. But as 1 barrel costs around $100 \$$, it is a substantial amount of money. Its deficiency strikes on Syria's budget. Russia and China hinder the development of the Syrian armed conflict and the USA assesses their position very negatively, claiming that the Russians defend their naval base in Tartus and the Chinese are ready to do anything in order to buy several extra barrels of oil.

\section{CONCLUDING REMARKS}

Rapid development of the Chinese economy, accompanied by its growing military power, is qualified in official documents as a threat to national security of the United States. Official Beijing is rather reserved and avoids direct confrontation, while America uses any means to dramatize the situation. Consistent and accurate strategy of development gives Beijing an opportunity to use such resource as time struggling for leading positions in the global market of technology and investments. However, relying on power, influence and authority, the Americans are confident that they can afford a bigger and riskier game. Time and rational long-term investments are becoming the most important competitive advantage.

\section{REFERENCES}

Agency of financial and economic information «Bloomberg» Retrieved from http://www.bloomberg.com

Business magazine «ChinaPro» Retrieved from http://www.chinapro.ru/

Informative web-portal «Rosbalt» Retrieved from http://www.rosbalt.ru/business/

International Chamber of Commerce Retrieved from http://www.iccwbo.org

Monthly scientific journal «The Economist» Retrieved from http://www.economist.com.ru/

Online version of the Journal of International Business News «Business Week» Retrieved from http://www.businessweek.com

Primljeno: 26.12.2014.

Odobreno: 29.12.2014. 